\title{
Employee Engagement: A Literature Review
}

\author{
Li Sun \\ PhD Candidate, School of Management, Shinawatra University \\ 99 Moo 10 Bang Toey, Sam Khok District, Pathum Thani 12160, Thailand \\ E-mail: sunli_lizhi@163.com
}

Chanchai Bunchapattanasakda (corresponding author)

Assistant Professor, School of Management, Shinawatra University

99 Moo 10 Bang Toey, Sam Khok District, Pathum Thani 12160, Thailand

E-mail: alaskatornado@gmail.com

Received: Dec. 5, 2018 Accepted: Dec. 20, 2018 Online published: Jan. 3, 2019

doi:10.5296/ijhrs.v9i1.14167ＵRL: https://doi.org/10.5296/ijhrs.v9i1.14167

\begin{abstract}
Employee engagement is an important issue in management theory and practice. However, there are still major differences in the concept, theory, influencing factors and outcomes of employee engagement, and there is still no authoritative standard. This paper attempts to review and summarize previous research results on employee engagement. Two kinds of definitions of employee engagement are identified: employee engagement as a multi-faceted construct (cognition, emotions and behaviors) and as a unitary construct (a positive state of mind, a dedicated willingness, the opposite of burnout). Three theoretical frameworks are used to explain the varying degrees of employee engagement: Needs-Satisfaction framework, Job Demands-Resources model and Social Exchange Theory. The influencing factors of employee engagement are divided into three categories: organizational factors (management style, job rewards, etc.), job factors (work environment, task characteristics, etc.) and individual factors (physical energies, self-consciousness, etc.). Employee engagement is found to have a positive relationship with individual performance (organizational commitment, positive behavior, etc.) and organizational performance (customer satisfaction, financial return, etc.) The research findings show that there are three shortcomings in previous studies: lack of research on demographic variables, personality differences and cross-cultural differences in employee engagement, lack of research on the mediating or moderating role of employee engagement, and lack of intervention mechanism for employee
\end{abstract}


engagement.

Keywords: employee engagement, literature review, recommendations

\section{Introduction}

Employee Engagement has been a hot research topic among positive psychologists, human resource researchers and management practitioners in recent years. Because of the emergence of positive psychology, work engagement, as a positive aspect of psychology, is increasingly popular in occupational health psychology. Engaged employees have a sense of energetic and effective connection with their work activities and see themselves as able to deal well with the demands of their job (Schaufeli \& Bakker, 2004). Due to the needs of business practice, many consulting organizations are conducting continuous research on employee engagement by surveying employers and employees. Despite a plethora of research on employee engagement, there is a lack of the consistency in its definitions, measures, antecedents and outcomes. Besides, due to cultural differences, the same engagement techniques do not necessarily work for employees in all countries. In the global context, there is no systematic review of the results of the study on employee engagement to date. This review examined the electronic academic journals of EBSCO database, DOAJ database, Google Scholar and CNKI database, electronic books and paper books in English and Chinese.

Objectives of Study

1) Synthesize the definitions and theoretical basis of employee engagement.

2) Synthesize the antecedents associated with employee engagement

3) Synthesize the outcomes associated with employee engagement

\section{Definitions of Employee Engagement}

There are different definitions of employee engagement among different scholars, organizations and different countries (Table 1). The concept of employee engagement was first proposed by Kahn (1990) as the harnessing of organization members' selves to their work roles; self-employment and self-expression of people physically, cognitively, and emotionally in their work lives. Since Kahn proposed this concept, researchers have proposed different definitions which reflect different understanding of employee engagement in each study, but this caused confusion for business management whether the efforts which improve employee engagement are working in all organizations.

\subsection{Employee Engagement as a Multi-faceted Construct}

May et al. (2004) stated that employee engagement included not only cognition, but also the flexible application of emotions and behaviors. Wellins and Concelman (2005) stated that engagement is a mixture of commitment, loyalty, productivity, and ownership. Saks (2006) defined employee engagement as a "different and unique concept" which is composed of knowledge, emotion and behavior. Cha (2007) defined employee engagement as the employee's active involvement in work and the state of full physiology, cognition, and emotion that accompanies the work engagement, including three dimensions: work 
engagement, organizational recognition, and sense of work value. Macey and Schneider (2008) suggested to regard employee engagement as a wide-ranging term which contains different types of engagement (traits engagement, psychological state engagement, behavioral engagement), and each one needs different conceptualizations, such as proactive personality (traits engagement), involvement (psychological state engagement) and organizational citizenship behavior (behavioral engagement). Bakker (2011) summed the engagement as a positive, highly awakened emotional state with two features: energy, and involvement. Soane et al. (2012) developed a model of employee engagement that has three requirements: a work-role focus, activation and positive affect. Xu et al. (2013) divided employee engagement into four dimensions: organizational identity, work attitude, mental state, responsibility effectiveness. Xiao and Duan (2014) stated that employee engagement was a conceptualization including five dimensions: initiative, loyalty, effectiveness, identity and commitment. Liu (2016) stated that employee engagement of knowledge worker was composed of five dimensions: organizational identity, dedication, absorption, vigor, pleasant harmony.

\subsection{Employee Engagement as a Dedicated Willingness}

Hewitt Organization (2001) referred to employee engagement as the extent employees are willing to stay in the company and work hard for the company, reflected in three aspects: 1) "Say": employees use a positive language to describe their company, colleagues, and their jobs. 2) "Stay": employees strongly hope to be a member of the company, want to stay in the company for a long time, instead of using existing jobs as a temporary transition. 3) "Strive": employees are willing to devote extra effort to work for the success of the company. Towers organization (2001) defined employee engagement as the degree of willingness and ability of employees to help companies succeed, dividing it into rational engagement and sensuous engagement. Rational engagement generally involves the relationship between individuals and companies, such as the degree of employees' understanding of their roles and departmental roles. When work can bring money, professional skills or personal development and other benefits, employees will generate the sense of rational engagement. Sensuous engagement depends on employee satisfaction, and the sense of self-achievement from job as a member of the organization (Fang et al., 2010). Xie (2006) pointed out that employee engagement is employee' dedication to a profession, including hard work, dedicated to the company, loyal to the boss, and self-confidence.

\subsection{Employee Engagement as a Positive State of Mind}

Schaufeli et al. (2002) defined engagement as a positive, fulfilling, work-related state of mind that is characterized by vigor, dedication, and absorption, and a more persistent and pervasive affective-cognitive state that is not focused on any specific object, event, individual, or behavior. Harter et al. (2002) defined employee engagement as the individual's involvement and satisfaction with as well as enthusiasm for work. Zeng and Han (2005) referred to employee engagement as having a long-lasting, positive emotional and motivational state of awakening their work, ready to devote themselves to work at any time, and are accompanied by pleasant, proud, and encouraging experiences during work. 


\subsection{Employee Engagement as the Opposite of Burnout}

Maslach et al. (2001) stated that engagement is an energy, participation, and effectiveness, corresponding with three features of burnout: exhaustion, cynicism and reduced professional efficacy, and engagement and burnout are two ends of a continuum. Schaufeli and Bakker (2004) stated that vigor and dedication are direct opposites of exhaustion and cynicism, respectively. González-Romá et al. (2006) expanded two groups of opposite dimensions (emotional exhaustion-vigor, cynicism-dedication) as two different and latent dimensions (energy and identity). Demerouti et al. (2010) stated that cynicism and dedication are two ends of "identity" dimension, while emotional exhaustion and vigor are not supported as two ends of the "energy" dimension.

Table 1. Definitions of employee engagement

\begin{tabular}{|c|c|c|}
\hline Authors & Definitions & Category \\
\hline $\begin{array}{l}\text { Kahn } \\
(1990)\end{array}$ & $\begin{array}{l}\text { The harnessing of organization } \\
\text { members' selves to their work } \\
\text { roles; in engagement, people } \\
\text { employ and express themselves } \\
\text { physically, cognitively, and } \\
\text { emotionally during role } \\
\text { performances }\end{array}$ & \multirow{7}{*}{$\begin{array}{l}\text { Employee engagement as a } \\
\text { multi-faceted construct }\end{array}$} \\
\hline $\begin{array}{l}\text { May et al. } \\
(2004)\end{array}$ & $\begin{array}{l}\text { How the organization's members } \\
\text { devote themselves to work, } \\
\text { including not only cognition, but } \\
\text { also the flexible application of } \\
\text { emotions and behaviors }\end{array}$ & \\
\hline $\begin{array}{l}\text { Wellins \& } \\
\text { Concelman } \\
\text { (2005) }\end{array}$ & $\begin{array}{l}\text { A mixture of commitment, loyalty, } \\
\text { productivity, and ownership }\end{array}$ & \\
\hline $\begin{array}{l}\text { Saks } \\
(2006)\end{array}$ & $\begin{array}{l}\text { The combination of knowledge, } \\
\text { emotion and behavior related to the } \\
\text { individual's role performance }\end{array}$ & \\
\hline $\begin{array}{l}\text { Cha } \\
(2007)\end{array}$ & $\begin{array}{l}\text { Employee's active involvement in } \\
\text { work and the state of full } \\
\text { physiology, cognition, and emotion } \\
\text { that accompanies the work } \\
\text { engagement, including three } \\
\text { dimensions: work engagement, } \\
\text { organizational recognition, and } \\
\text { sense of work value }\end{array}$ & \\
\hline $\begin{array}{l}\text { Bakker } \\
(2011)\end{array}$ & $\begin{array}{l}\text { A positive, highly awakened } \\
\text { emotional state with two features: } \\
\text { energy, and involvement }\end{array}$ & \\
\hline $\begin{array}{l}\text { Macey \& } \\
\text { Schneider } \\
\text { (2008) }\end{array}$ & $\begin{array}{l}\text { A wide-ranging term which } \\
\text { contains different types of } \\
\text { engagement (traits engagement, } \\
\text { psychological state engagement, } \\
\text { behavioral engagement) }\end{array}$ & \\
\hline
\end{tabular}


Table 1. (continued)

\begin{tabular}{|c|c|c|}
\hline Authors & Definitions & Category \\
\hline $\begin{array}{c}\text { Soane et al. } \\
(2012)\end{array}$ & $\begin{array}{l}\text { A work-role focus, activation and } \\
\text { positive affect. }\end{array}$ & \multirow{4}{*}{$\begin{array}{l}\text { Employee engagement as a } \\
\text { multi-faceted construct }\end{array}$} \\
\hline $\begin{array}{c}\text { Xu et al. } \\
(2013)\end{array}$ & $\begin{array}{l}\text { Employees' organizational identity, } \\
\text { work attitude, mental state, } \\
\text { responsibility effectiveness }\end{array}$ & \\
\hline $\begin{array}{l}\text { Xiao \& } \\
\text { Duan } \\
(2014)\end{array}$ & $\begin{array}{l}\text { Employees' } \begin{array}{l}\text { initiative, loyalty, } \\
\text { effectiveness, recognition and } \\
\text { commitment }\end{array} \\
\end{array}$ & \\
\hline $\begin{array}{c}\text { Liu } \\
(2016)\end{array}$ & $\begin{array}{l}\text { Employees' organizational identity, } \\
\text { dedication, absorption, vigor, } \\
\text { pleasant harmony }\end{array}$ & \\
\hline $\begin{array}{l}\text { Hewitt } \\
\text { Consulting } \\
(2001)\end{array}$ & $\begin{array}{l}\text { The extent how employees are } \\
\text { willing to stay in the company and } \\
\text { work hard for the company, } \\
\text { including three elements: say, stay } \\
\text { and strive }\end{array}$ & \multirow{3}{*}{$\begin{array}{l}\text { Employee engagement as a } \\
\text { dedicated willingness }\end{array}$} \\
\hline $\begin{array}{l}\text { Towers } \\
\text { Consulting } \\
(2001)\end{array}$ & $\begin{array}{l}\text { Degree of willingness and ability } \\
\text { of employees to help companies } \\
\text { succeed, including rational and } \\
\text { sensuous engagement }\end{array}$ & \\
\hline $\begin{array}{l}\text { Xie } \\
(2006)\end{array}$ & $\begin{array}{l}\text { A sense of professional } \\
\text { responsibility, including hard work, } \\
\text { dedicated to the company, loyal to } \\
\text { the boss, and self-confidence }\end{array}$ & \\
\hline $\begin{array}{l}\text { Schaufeli et } \\
\text { al. } \\
\text { (2002) }\end{array}$ & $\begin{array}{l}\text { A positive, fulfilling, work-related } \\
\text { state of mind that is characterized } \\
\text { by vigor, dedication, and } \\
\text { absorption }\end{array}$ & \multirow{3}{*}{$\begin{array}{l}\text { Employee engagement as a } \\
\text { positive state of mind }\end{array}$} \\
\hline $\begin{array}{l}\text { Harter et al. } \\
\qquad(2002)\end{array}$ & $\begin{array}{l}\text { The individual's involvement and } \\
\text { satisfaction with as well as } \\
\text { enthusiasm for work }\end{array}$ & \\
\hline $\begin{array}{l}\text { Zeng \& Han } \\
\quad(2005)\end{array}$ & $\begin{array}{l}\text { Having a long-lasting, positive } \\
\text { emotional and motivational state of } \\
\text { awakening their work, ready to } \\
\text { devote themselves to work at any } \\
\text { time, and are accompanied by } \\
\text { pleasant, proud, and encouraging } \\
\text { experiences during work }\end{array}$ & \\
\hline
\end{tabular}


Table 1. (continued)

\begin{tabular}{c|l|c}
\hline Authors & \multicolumn{1}{|c|}{ Definitions } & Category \\
\hline $\begin{array}{c}\text { Maslach et al. } \\
(2001)\end{array}$ & $\begin{array}{l}\text { The opposites of three features of } \\
\text { burnout: energy, participation, and } \\
\text { effectiveness }\end{array}$ & \\
\hline $\begin{array}{c}\text { Schaufeli \& } \\
\text { Bakker } \\
(2004)\end{array}$ & $\begin{array}{l}\text { The opposites of two features of } \\
\text { burnout: vigor and Dedication }\end{array}$ & $\begin{array}{c}\text { Employee engagement as the } \\
\text { opposite of burnout }\end{array}$ \\
$\begin{array}{c}\text { González-Romá } \\
\text { et al. (2006) }\end{array}$ & $\begin{array}{l}\text { The opposite of cynicism of } \\
\text { burnout: dedication }\end{array}$ & \\
\hline $\begin{array}{c}\text { Demerouti et al. } \\
(2010)\end{array}$ & Independent of burnout: vigor & \\
\hline
\end{tabular}

\section{Theoretical Frameworks of Employee Engagement}

A wide range of theoretical frameworks have been used to explain employee engagement. Different researchers explain employee engagement from different theoretical perspectives in their own empirical study. There is no unique theoretical framework for employee engagement to date. In this review, needs-satisfaction framework, JD-R Framework and social exchange theory are discussed to explain employee engagement as follows (Table 2).

The needs-satisfaction framework is first reflected in Kahn's (1990) definition of engagement. Kahn (1990) supposed that employees are more engaged in their work, when three psychological needs are satisfied: meaningfulness (sense of return on investments of self in role performance), safety (sense of being able to show and employ self without fear of negative consequences to self-image, status, or career), availability (sense of possessing the physical, emotional, and psychological resources necessary for investing self in role performances). When the organization fails to provide these resources, individuals are more likely to withdraw and defend themselves from their roles. Meaningfulness is influenced by the nature of the job; that is, its tasks, roles, and work interactions. Psychological safety is mainly influenced by the social environment; that is, by interpersonal relationships, group and intergroup dynamics, management style and process, and organizational norms. Finally, availability depends on the personal resources that people can bring to their role performance, such as physical energies, emotional energies, insecurity and outside life.

Employee engagement is also affected by Job Demands-Resources Model (Salanova et al., 2005; Bakker et al., 2005; Hakanen et al., 2006; Schaufeli et al., 2009; Xanthopoulou et al., 2009; Crawford et al., 2010; Salminen et al., 2014). Job Demands-Resources (JD-R) model believe that different organizations may be confronted with different working environments, but the characteristics of these environments can be always classified in two general categories - job demands and job resources - thus constituting an overarching model that may be applied to various occupational settings, irrespective of the particular demands and resources involved. Job demands refer to those physical, psychological, social, or organizational aspects of the job that require sustained physical and/or psychological (cognitive and emotional) effort and are therefore associated with certain physiological and/or 
psychological costs. Examples are a high work pressure, role overload, poor environmental conditions and problems related to reorganization. Job resources refer to those physical, psychological, social, or organizational aspects of the job that are either/or: (1) functional in achieving work goals; (2) reduce job demands and the associated physiological and psychological costs; (3) stimulate personal growth and development (Bakker et al., 2003). Thus, the JD-R model can explain the assumption that employees are more likely to engage with their work when they get job-related resources from the organization.

A stronger theoretical rationale for explaining employee engagement can be found in social exchange theory (SET). Levinson (1965) stated that employment is a transaction between labor, loyalty and actual interest, and social rewards. To a certain extent, the relationship between employee and employer is suitable for reciprocity, in which a request for return will lead to beneficial results to both parties no matter who gain the preferential treatment. Masterson et al. (2000) proposed that one party expects a return in the future after contributing or providing services to the other party. At the same time, the party that gets something of value will produce a sense of responsibility to return the other party. For individuals who have helped them, employees will actively give a return to gain more benefits in the future. Many scholars analyzed the relationship between organization and members based on social exchange theory. Employees are loyal to the organization and work hard in exchange for economic benefits and social rewards, establishing the organization-employee relationship. Eisenberger et al. (1986) stated that high levels of perceived organizational support create obligations within individuals to repay the organization, thereby demonstrating an attitude and behavior conducive to the organization. Saks (2006) argued that one way for individuals to repay their organization is through their level of engagement. In other words, employees will choose to engage themselves to varying degrees in response to the resources they received from their organization.

Table 2. Theoretical frameworks of employee engagement

\begin{tabular}{c|c|l}
\hline Theories & Authors & \multicolumn{1}{c}{ Characteristics } \\
\hline \multirow{2}{*}{$\begin{array}{c}\text { Needs-Satisfaction } \begin{array}{c}\text { Kahn } \\
\text { Framework }\end{array} \\
(1990)\end{array}$} & \begin{tabular}{l} 
Meaningfulness: sense of return on investments of \\
self in role performance \\
\cline { 3 - 3 }
\end{tabular} & $\begin{array}{l}\text { Safety: sense of being able to show and employ } \\
\text { self without fear of negative consequences to } \\
\text { self-image, status, or career }\end{array}$ \\
\hline $\begin{array}{l}\text { Availability: sense of possessing the physical, } \\
\text { emotional, and psychological resources necessary } \\
\text { for investing self in role performances }\end{array}$ \\
\hline
\end{tabular}


Table 2. (continued)

\begin{tabular}{|c|c|c|}
\hline Theories & Authors & Characteristics \\
\hline \multirow[t]{2}{*}{$\begin{array}{l}\text { Job } \\
\text { Demands-Resources } \\
\text { Model }\end{array}$} & \multirow[t]{2}{*}{$\begin{array}{l}\text { Bakker et al. } \\
\qquad(2003)\end{array}$} & $\begin{array}{l}\text { Job demands refer to those physical, psychological, } \\
\text { social, or organizational aspects of the job that } \\
\text { require sustained physical and/or psychological } \\
\text { (cognitive and emotional) effort and are therefore } \\
\text { associated with certain physiological and/or } \\
\text { psychological costs. }\end{array}$ \\
\hline & & $\begin{array}{l}\text { Job resources refer to those physical, } \\
\text { psychological, social, or organizational aspects of } \\
\text { the job that are either/or: 1) functional in achieving } \\
\text { work goals; 2) reduce job demands and the } \\
\text { associated physiological and psychological costs; } \\
\text { 3) stimulate personal growth and development. }\end{array}$ \\
\hline \multirow[t]{4}{*}{$\begin{array}{c}\text { Social Exchange } \\
\text { Theory }\end{array}$} & $\begin{array}{l}\text { Levinson } \\
(1965)\end{array}$ & $\begin{array}{l}\text { A request for return will lead to beneficial results to } \\
\text { both parties no matter who gain the preferential } \\
\text { treatment. }\end{array}$ \\
\hline & $\begin{array}{l}\text { Masterson et } \\
\text { al. (2000) }\end{array}$ & $\begin{array}{l}\text { One party expects a return in the future after } \\
\text { contributing or providing services to the other } \\
\text { party. At the same time, the party that gets } \\
\text { something of value will produce a sense of } \\
\text { responsibility to return the other party. }\end{array}$ \\
\hline & $\begin{array}{c}\text { Eisenberger et } \\
\text { al. } \\
(1986)\end{array}$ & $\begin{array}{l}\text { High levels of perceived organizational support } \\
\text { create obligations within individuals to repay the } \\
\text { organization, thereby demonstrating an attitude and } \\
\text { behavior conducive to the organization. }\end{array}$ \\
\hline & $\begin{array}{l}\text { Saks } \\
(2006)\end{array}$ & $\begin{array}{l}\text { Employees will choose to engage themselves to } \\
\text { varying degrees and in response to the resources } \\
\text { they receive from their organization. }\end{array}$ \\
\hline
\end{tabular}

\section{Antecedents and Outcomes of Employee Engagement}

Employee engagement refers to employees' physical, cognitive and emotional input in the work. Past researches showed that the influencing factors of employee engagement can be summarized as three categories: organizational factors (leadership, superior support, job resources, fairness, etc.), job factors (work environment, job participation, job enrichment, etc.) and individual factors (extraversion, resilience, self-consciousness, etc.). The research on consequences of employee engagement mainly focus on two aspects- the influence of employee engagement on individual performance (enthusiasm, excellence, satisfaction, devotion, etc.) and on organizational performance (productivity, profitability, customer loyalty, etc.) 


\subsection{Antecedents of Employee Engagement}

The antecedent variables of employee engagement can be divided into three categories: organizational factors, job factors and individual factors (see Table 3). Most of researches focus on one or two of the three factors, except for the research of May et al. (2004). Kahn (1990) proposed that task characteristics, role characteristics, work interaction, group and inter-group dynamics, management style \& process, organizational norms have an influence on employee engagement. Harter et al. (2002) pointed out that work environment, direct supervisor, senior management team, colleagues have an influence on employee engagement. Salanova and Schaufeli (2008) stated that job control, job participation, job feedback, job rewards, job security, supervisor support have an influence on employee engagement. May et al. (2004) stated that job enrichment, work role fit, rewarding co-worker, supportive supervisor and self-consciousness have an influence on employee engagement. Zhang and Gan (2005) found that support, sense of fairness, interpersonal consumption, and conflict have an influence on employee engagement. The research of Langelaan et al. (2006) stated that neuroticism, extraversion and mobility have an influence on employee engagement.

Job demands-resources theory believes that job resources and personal resources independently or together predict employee engagement. When high job requirements are required, job resources and personal resources have a more positive impact on employee engagement. Therefore, job resources and job demands are two very important antecedent variables for employee engagement. Job resources can reduce the impact of job demands, promote job goal and stimulate personal growth, learning and development. Schaufeli and Bakker (2004), Bakker and Demerouti (2008), Xanthopoulou et al. (2009) stated that the available job resources are the main predictors of engagement. Farndale's (2015) study showed that certain job resources (financial returns, team atmosphere, participation in decision-making) positively affect employee engagement in three countries (Mexico, Netherlands, and the United States). The cross-cultural theory was used to explain the difference in the intensity of the relationship between these job resources and engagement.

In terms of personal resources, dedicated employees seem to be different from other employees, including optimism, self-efficacy, and self-esteem, resilience, positive coping style, and demographic variables. These resources can help dedicated employee control and influence their work environment, so personal resources can promote employee dedication. Bakker et al. (2006) found that resilience is an individual resource that promotes employee engagement in the study of female headmasters. Xanthopoulou (2009) also studied personal resources such as self-efficacy, self-esteem, and optimism as important factors in predicting engagement. Empirical analysis of Rich et al. (2010) showed that nuclear self-evaluation (self-esteem, self-efficacy, control points and stable emotion) and engagement are positively correlated. Simbula et al. (2011) found that self-efficacy has a short-term (4 months) and long-term (8 months) lag impact on engagement. Christian et al. (2011) showed that there is a positive correlation between responsibility, positive emotions, positive personality, and engagement. Gan and Gan's (2014) empirical study showed that extraversion, conscientiousness affect engagement through job requirements or resources. The study of Roof (2015) showed that there is a relationship between spirituality and vigor and dedication. 


\section{Macrothink}

International Journal of Human Resource Studies

ISSN 2162-3058 2019, Vol. 9, No. 1

Thompson et al. (2015) stated the direct and indirect impact of positive psychological capital on employee engagement. In the longitudinal study of Korean hotel employees, Paek et al. (2015) found that front-line staff with high psychological capital invest more in their own work.

Table 3. Antecedents of employee engagement

\begin{tabular}{|c|c|c|}
\hline Authors & Antecedents & Categories \\
\hline \multirow[t]{3}{*}{ Kahn (1990) } & $\begin{array}{l}\text { task characteristics, role } \\
\text { characteristics, work interaction }\end{array}$ & job factors \\
\hline & $\begin{array}{l}\text { group and inter-group dynamics, } \\
\text { management style and process, } \\
\text { organizational norms }\end{array}$ & organizational factors \\
\hline & $\begin{array}{l}\text { physical energies, emotional } \\
\text { energies, insecurity, outside life }\end{array}$ & individual factors \\
\hline \multirow{2}{*}{$\begin{array}{l}\text { Harter et al. } \\
\qquad(2002)\end{array}$} & work environment, & job factors \\
\hline & $\begin{array}{l}\text { direct supervisor, senior } \\
\text { management team, colleagues }\end{array}$ & organizational factors \\
\hline \multirow{3}{*}{$\begin{array}{l}\text { May et al. } \\
(2004)\end{array}$} & job enrichment & job factor \\
\hline & $\begin{array}{l}\text { work role fit, rewarding co-worker, } \\
\text { supportive supervisor }\end{array}$ & organizational factors \\
\hline & self-consciousness & individual factor \\
\hline $\begin{array}{c}\text { Schaufeli \& } \\
\text { Bakker (2004), } \\
\text { Bakker \& } \\
\text { Demerouti (2008) } \\
\text { Xanopoulou et al. } \\
\text { (2009) }\end{array}$ & available job resources & organizational factor \\
\hline $\begin{array}{l}\text { Zhang \& Can } \\
\quad(2005)\end{array}$ & $\begin{array}{l}\text { support, sense of fairness, } \\
\text { interpersonal consumption, and } \\
\text { conflict }\end{array}$ & organizational factors \\
\hline $\begin{array}{l}\text { Langelaan et al. } \\
\qquad(2006)\end{array}$ & $\begin{array}{l}\text { neuroticism, extraversion and } \\
\text { mobility }\end{array}$ & individual factors \\
\hline $\begin{array}{l}\text { Bakker et al. } \\
\text { (2006) }\end{array}$ & resilience & individual factors \\
\hline $\begin{array}{c}\text { Salanova et } \\
\text { Schaufeli (2008) }\end{array}$ & $\begin{array}{l}\text { job control, job participation, job } \\
\text { feedback, job rewards, job security, } \\
\text { supervisor support }\end{array}$ & organizational factors \\
\hline $\begin{array}{l}\text { Xanthopoulou } \\
\text { (2009) }\end{array}$ & $\begin{array}{l}\text { self-efficacy, self-esteem, and } \\
\text { optimism }\end{array}$ & individual factors \\
\hline
\end{tabular}


Table 3. (continued)

\begin{tabular}{|c|c|c|}
\hline Authors & Antecedents & Categories \\
\hline $\begin{array}{c}\text { Rich et al. } \\
(2010)\end{array}$ & $\begin{array}{l}\text { self-esteem, self-efficacy, control } \\
\text { points and stable emotion }\end{array}$ & individual factors \\
\hline $\begin{array}{l}\text { Simbula et al. } \\
\text { (2011) }\end{array}$ & self-efficacy & individual factors \\
\hline $\begin{array}{l}\text { Christian et al. } \\
\qquad(2011)\end{array}$ & $\begin{array}{l}\text { responsibility, positive emotions, } \\
\text { positive personality }\end{array}$ & individual factors \\
\hline $\begin{array}{l}\text { Gan \& Gan } \\
\text { (2014) }\end{array}$ & extraversion, conscientiousness & individual factors \\
\hline $\begin{array}{c}\text { Roof } \\
(2015) \\
\end{array}$ & spirituality & individual factors \\
\hline $\begin{array}{c}\text { Thompson et al. } \\
\text { (2015) } \\
\text { Paek et al. } \\
(2015)\end{array}$ & positive psychological capital & individual factors \\
\hline $\begin{array}{c}\text { Farndale } \\
(2015)\end{array}$ & $\begin{array}{l}\text { financial returns, team atmosphere, } \\
\text { participation in decision-making }\end{array}$ & organizational factors \\
\hline
\end{tabular}

\subsection{Outcomes of Employee Engagement}

At present, the research on employee engagement outcomes are mainly focused on two aspects -individual performance and organizational performance, among which, the relationship between employee engagement and organizational performance is the focus of current research (Table 4).

Dedicated employees are more active in their work, have better health, and perform better (Susana et al., 2007). Compared with employees who are not dedicated, dedicated employees get more satisfaction from work, higher organizational commitment, and less willingness to leave the organization (Yang, 2005). Dedicated employees have positive behavior (Wilmar \& Arnold, 2006). Overall, dedicated employees have more active organizational behaviors and are willing to pay more. This has been validated in the study of Dutch employees, in which engaged employees have more overtime than disengaged employees (Sonnentag, 2003). Salanova et al. (2005) studied the relationship between organizational resources, employee engagement, and employee performance. Based on a survey of 342 employees in 114 hotels, it was concluded that organizational resources can have a positive impact on employee engagement, in turn, employee engagement will have a positive impact on employee performance. Saks (2006), based on the research conducted on 102 employees from different organizations, concluded that employee engagement has a positive impact on organizational citizenship behavior. In the theoretical model constructed by Bakker and Demerouti (2008), employee engagement has a positive effect on employees' out-of-role performance.

Some empirical researched showed that there is a positive correlation between employee engagement and organizational performance. Harter et al. (2002) research showed that the correlation between employee engagement and employee turnover is -0.30 , the correlation 
with customer satisfaction is 0.33 , and the correlation with employee profit is 0.17 . Salanova et al. (2005) found that the level of employee engagement can affect the organization's service climate through the study of the quality of hotel and restaurant services, and thus affect the performance of employees and customer loyalty. Wyatt Consulting's research showed that employee engagement is closely related to shareholder returns. The average return to shareholders by employees with lower engagement, medium engagement, and high engagement within 3 years are 76 percent, 90 percent and 112 percent, respectively (Zhao \& Sun, 2010). Xanthopoulou et al. (2009) stated that employee engagement can have a positive effect on the financial performance of the organization. Based on human strengths, after years of empirical analysis, Harter et al. (2002) proved that employee engagement is a "soft index" that affects organizational performance, and it is related to the five major indicators of organizational performance - productivity, profitability, customer loyalty, employee retention, and security.

Table 4. Outcomes of employee engagement

\begin{tabular}{c|l|l}
\hline Authors & \multicolumn{1}{|c|}{ Outcomes } & \multicolumn{1}{c}{ Categories } \\
\hline $\begin{array}{c}\text { Xanthopoulou } \\
(2009)\end{array}$ & $\begin{array}{l}\text { financial performance of the } \\
\text { organization }\end{array}$ & organizational performance \\
\hline $\begin{array}{c}\text { Harter et al. } \\
(2002)\end{array}$ & $\begin{array}{l}\text { employee profit, employee } \\
\text { turnover }\end{array}$ & individual performance \\
\cline { 2 - 3 } & $\begin{array}{l}\text { customer } \\
\text { organization's satisfaction, } \\
\text { climate }\end{array}$ & organizational performance \\
\hline $\begin{array}{c}\text { Sonnentag } \\
(2003)\end{array}$ & more overtime & individual performance \\
\hline $\begin{array}{c}\text { Salanova et al. } \\
(2005)\end{array}$ & employee performance & individual performance \\
\hline $\begin{array}{c}\text { Yang } \\
(2005)\end{array}$ & $\begin{array}{l}\text { more satisfaction from work, } \\
\text { higher } \\
\text { commitment, organizational } \\
\text { willingness to leave }\end{array}$ & individual performance \\
\hline $\begin{array}{c}\text { Wilmar \& Arnold } \\
(2006)\end{array}$ & positive behavior & individual performance \\
\hline $\begin{array}{c}\text { Saks } \\
(2006)\end{array}$ & $\begin{array}{l}\text { organizational citizenship } \\
\text { behavior }\end{array}$ & individual performance \\
\hline $\begin{array}{c}\text { Suana et al. } \\
(2007)\end{array}$ & $\begin{array}{l}\text { more active in work, better } \\
\text { health, better performance }\end{array}$ & individual performance \\
\hline $\begin{array}{c}\text { Bakker \& } \\
\text { Demerouti } \\
(2008)\end{array}$ & $\begin{array}{l}\text { employees' out-of-role } \\
\text { performance }\end{array}$ & individual performance \\
\hline $\begin{array}{c}\text { Zhao \& Sun } \\
(2010)\end{array}$ & return to shareholders & organizational performance \\
\hline
\end{tabular}

\section{Conclusion}

\subsection{Summary}

Employee engagement is an important concept to organizational leaders and employees alike. This paper, through the review of definitions, theories, antecedents and outcomes of employee engagement, highlighted what the body of research has indicated on the topic of employee engagement. Employee engagement usually refers to employees' physical, 
cognitive and emotional input in the work. Needs-Satisfaction framework, Job Demands-Resources model and Social Exchange Theory have been used to explain varying levels of employee engagement in the organizations. According to Needs-Satisfaction framework, employees' sense of meaningfulness of work elements, job security and the availability of personal resources determine their engagement in role performances. According to JD-R model, high-levels of job-related and personal resources can reduce the exhaustion and other negative outcomes caused by job demands which require employees to pay additional efforts. According to social exchange theory, relationships between employees and employers are based on norms of reciprocity. When employees feel that they are being treated well and valued by their employer, they are more likely to respond by exerting effort on behalf of the employer in the form of raised levels of engagement (Alfes et al., 2013a). With regard to variables related to employee engagement, antecedent variables mainly include three categories: organizational factors, job factors and individual factors, and outcome variables are mainly focused on individual performance and organizational performance.

\subsection{Discussion}

The literature review of employee engagement reflected the following results. First, employee engagement starts with the personal work experience and is a typically individual decision that cannot be forced. It involves individual employees, not organizations. Therefore, employee engagement is an individual-level concept, not a group-level concept. Second, employee engagement is an active, work-related psychological state that includes perceptions, emotions, and behaviors, with the features of energy and involvement. Thus, engagement can be experienced emotionally, cognitively, and be displayed behaviorally. Third, the relationship between burnout and engagement is complicated. The empirical results showed that burnout and engagement were two ends of the same continuum in one dimension (cynicism-dedication), but independent of each other in another dimension (emotional exhaustion-vigor). Therefore, engagement cannot simply be expressed in the opposite mode of burnout scores but requires a specialized and independent measurement. Fourth, employee engagement is a composite of attitude and behavior. The dedication, involvement, and other cognitive and emotional components in the engagement reflect the attitudes of the employees, while vigor and absorption reflect the employees' physical input and are displayed through employee behavior. Fifth, most of researches focus on the influencing factors (organizational, individual, job) of employee engagement, this indicates employee engagement is a widely concerned issue among the academia and business practitioners. Besides, the contributions of employee engagement to organizational performance indicates the critical role of engaged employees to the success of an enterprise.

\subsection{Limitation}

This paper made a literature review of employee engagement, but this review does not capture all the studies in areas related to employee engagement because of the limited time and resources. First, this review examined only some studies published in peer-viewed journals and books which are mainly viewed online. Second, there are too many research 
findings about the definitions, theoretical basis, antecedents and outcomes of employee engagement, this paper only reviewed some of them according to the author's propensity which will inevitably lead to bias and incompleteness of the review of employee engagement. Third, employee engagement in this review refers to individual engagement, not involving team engagement and organizational engagement.

\subsection{Recommendations for Future Research}

A wide range of studies have been conducted on employee engagement since Kahn (1990) made up the concept of engagement (Kahn, 1990), but there is still much research to be done in the area of employee engagement. From this literature review, there seems to be a lack of research focusing on the impact of employees' demographics, personality traits and cultural differences on engagement. The comparative studies of cross-national employee engagement are scarce except for famous Utrecht Work Engagement Scale. Besides, the researches on employee engagement are mainly focused on its antecedents and outcomes, neglecting the mediating or moderating role of employee engagement between some variables. Finally, this review shows a major deficiency that researchers have to pay attention to, that is, there is a lack of the research on the intervention measures which best reflect the practical values of employee engagement research in the human resource management field. Therefore, it's my hope that future research can explore the mediating or moderating role of employee engagement, enrich the antecedents of employee engagement by adding factors of demographics, personality, cross-culture, and make empirical studies on the intervention measures improving employee engagement by longitudinal survey so as to better guide management practice.

\section{Acknowledgement}

Thanks for Assistant Prof. Chanchai Bunchapattanasakda, Shinawatra University.

\section{References}

Alfes, K., Shantz, A. D., Truss, C., \& Soane, E. C. (2013a). The link between perceived human resource management practices, engagement and employee behavior: A moderated mediation model. International journal of human resource management, 24(2), 330-351. https://doi.org/10.1080/09585192.2012.679950

Bakker, A. B. (2011). An evidence-based model of work engagement. Current directions in psychological science, 20(4), 265-269. https://doi.org/10.1177/0963721411414534

Bakker, A. B., \& Demerouti, E. (2008). Towards a model of work engagement. Career development international, 13(3), 209-223. https://doi.org/10.1108/13620430810870476

Bakker, A. B., Demerouti, E., \& Euwema, M. C. (2005). Job resources buffer the impact of job demands on burnout. Journal of occupational health psychology, 10(2), 170-180. https://doi.org/10.1037/1076-8998.10.2.170

Bakker, A. B., Demerouti, E., Boer, E., \& Schaufelia, W. B. (2003). Job demands and job resources as predictors of absence duration and frequency. Journal of vocational behavior, 62, 
341-356. https://doi.org/10.1016/S0001-8791(02)00030-1

Bakker, A., Van, E. H., \& Euwema, M. (2006). Crossover of burnout and engagement in work teams. Work and occupations, 33(4), 464-489. https://doi.org/10.1177/0730888406291310

Cha, S. C. (2007). Research on structural modeling of enterprise employee engagement. Unpublished manuscript, Jinan University, Jinan, China.

Christian, M., Garza, A., \& Slaughter, J. (2011). Work engagement: A quantitative review and test of its relations with task and contextual performance. Personnel psychology, 64(1), 89-136. https://doi.org/10.1111/j.1744-6570.2010.01203.x

Crawford, E. R., LePine, J. A., \& Rich, B. L. (2010). Linking job demands and resources to employee engagement and burnout: A theoretical extension and meta-analytic test. Journal of Applied psychology, 95(5), 834-848. https://doi.org/10.1037/a0019364

Demerouti, E., Mostert, K., \& Bakker, A. (2010). Burnout and work engagement: A thorough investigation of the independency of both constructs. Journal of occupational health psychology, 15(3), 209-222. https://doi.org/10.1037/a0019408

Eisenberger, R., Huntington, R., Hutchison, S., \& Sowa, D. (1986). Perceived organizational $\begin{array}{lllll}\text { support. Journal of applied psychology, } & 71(3), \quad 500-507 .\end{array}$ https://doi.org/10.1037/0021-9010.71.3.500

Fang, L. T., Shi, K., \& Zhang, F. H. (2010). A literature review on employee engagement. Management review, 22(5), 47-55.

Farndale, E. (2015). Job resources and employee engagement: A cross-national study. Journal of managerial psychology, 30(5), 610-626. https://doi.org/10.1108/JMP-09-2013-0318

Gan, T., \& Gan, Y. (2014). Sequential development among dimensions of job burnout and engagement among IT employees. Stress and health: journal of the international society for the investigation of stress, 30(2), 122-133. https://doi.org/10.1002/smi.2502

González-Romá, V., Schaufeli, W. B., Bakker, A. B., \& Lloret, S. (2006). Burnout and work engagement: Independent factors or opposite poles? Journal of vocational behavior, 68(1), 165-174. https://doi.org/10.1016/j.jvb.2005.01.003

Hakanen, J. J., Bakker, A. B., \& Schaufeli, W. B. (2006). Burnout and work engagement among teachers. Journal of school psychology, 43(6), 495-513. https://doi.org/10.1016/j.jsp.2005.11.001

Harter, J. K., Schmidt, F. L., \& Hayes, T. L. (2002). Business-unit-level relationship between employee satisfaction, employee engagement, and business outcomes: A meta-analysis. Journal of applied psychology, 87(2), 268-279. https://doi.org/10.1037/0021-9010.87.2.268

Kahn, W. A. (1990). Psychological conditions of personal engagement and disengagement at work. Academy of management journal, 33(4), 692-724.

Langelaan, S., Bakker, A. B., van Doornen, L. J. P., \& Schaufeli, W. B. (2006). Burnout and 
work engagement: Do individual differences make a difference? Personality and individual differences, 40(3), 521-532. https://doi.org/10.1016/j.paid.2005.07.009

Levinson, H. (1965). Reciprocation: The relationship between man and organization. Administrative science quarterly, 9, 370-390. https://doi.org/10.2307/2391032

Liu, Z. A. (2016). Study on the development of structure model of engagement for knowledge $\begin{array}{llll}\text { employee. Business management, } & \text { 65-69. }\end{array}$ http://dx.doi.org/10.13395/j.cnki.issn.1009-0061.2016.11.018

Macey, W. H., \& Schneider, B. (2008). The meaning of employee engagement. Industrial and organizational psychology, 1(1), 3-30. https://doi.org/10.1111/j.1754-9434.2007.0002.x

Maslach, C., Schaufeli, W. B., \& Leiter, M. P. (2001). Job burnout. Annual review of psychology, 52(1), 397-422. https://doi.org/10.1146/annurev.psych.52.1.397

Masterson, S. S., Lewis, K., Goldman, B. M., \& Taylor, M. S. (2000). Integrating justice and social exchange: The differing effects of fair procedures and treatment on work relationship. Academy of management journal, 43(4), 738-748. https://doi.org/10.2307/1556364

May, D. R., Gilson, R. L., \& Harter, L. M. (2004). The psychological conditions of meaningfulness, safety and availability and the engagement of the human spirit at work. Journal of occupational and organizational psychology, 77(1), 11-37. https://doi.org/10.1348/096317904322915892

Paek, S., Schuckert, M., Kim, T. G. T., \& Lee, G. (2015). Why is hospitality employees' psychological capital important? The effects of psychological capital on work engagement and employee morale. International journal of hospitality management, 50, 9-26. https://doi.org/10.1016/j.ijhm.2015.07.001

Rich, B., Lepine, J., \& Crawford, E. (2010). Job engagement: Antecedents and effects on job performance. Academy of management journal, 53(3), 617-635. https://doi.org/10.5465/amj.2010.51468988

Roof, R. A. (2015). The association of individual spirituality on employee engagement: The spirit at work. Journal of business ethics, 130(3), 585-599. https://doi.org/10.1007/s10551-014-2246-0

Saks, A. (2006). Antecedents and consequences of employee engagement. Journal of managerial psychology, 21(7), 600-619. https://doi.org/10.1108/02683940610690169

Salanova, M., \& Schaufeli, W. B. (2008). A cross-national study of work engagement as a mediator between job resources and proactive behavior. International journal of human resource management, 19, 116-131. https://doi.org/10.1080/09585190701763982

Salanova, M., Agut, S., \& Peiro, J. M. (2005). Linking organizational resources and work engagement to employee performance and customer loyalty: The mediation of service climate. $\begin{array}{llll}\text { Journal of } \quad \text { applied } & \text { 90(6), } & \text { 1217-1227. }\end{array}$ https://doi.org/10.1037/0021-9010.90.6.1217 
Salminen, S. R., Mäkikangas, A., \& Feldt, T. (2014). Job resources and work engagement: Optimism as moderator among Finnish managers. Journal of European psychology students, 5(1), 69-77. https://doi.org/10.5334/jeps.bu

Schaufeli, W. B., \& Bakker, A. B. (2004). Utrecht work engagement scale: Preliminary manual. Utrecht university, 3-60.

Schaufeli, W. B., Bakker, A. B., \& Rhenen, W. V. (2009). How changes in job demands and resources predict burnout, work engagement, and sickness absenteeism. Journal of organizational behavior, 30(7), 893-917. https://doi.org/10.1002/job.595

Schaufeli, W. B., Salanova, M., Gonzalez-Roma, V., \& Bakker, A. B. (2002). The measurement of engagement and burnout: A two sample confirmative factor analytic approach. Journal of happiness studies, 3, 71-92. https://doi.org/10.1023/A:1015630930326

Shuck, B., \& Wollard, K. (2010). Employee engagement and HRD: A seminal review of the foundations. Human resource development review, 9(1), 89-110. https://doi.org/10.1177/1534484309353560

Simbula, S., Guglielmi, D., \& Schaufeli, W. (2011). A three-wave study of job resources, self-efficacy, and work engagement among Italian schoolteachers. European journal of work and organizational psychology, 20(3), 285-304. https://doi.org/10.1080/13594320903513916

Soane, E., Truss, C., Alfes, K., Shantz, A., Rees, C., \& Gatenbytt, M. (2012). Development and application of a new measure of employee engagement: The ISA engagement scale. Human resource development international, 15(5), 529-547. https://doi.org/10.1080/13678868.2012.726542

Sonnentag, S. (2003). Recovery, work engagement, and proactive behavior: A new look at the interface between nonwork and work. Journal of applied psychology, 88(3), 518-528. https://doi.org/10.1037/0021-9010.88.3.518

Susana, L., Schaufeli, W., Bakker, A., \& Salanova, M. (2007). Does a positive gain spiral of resources, efficacy beliefs and engagement exist? Computers in human behavior, 23, 825-841. https://doi.org/10.1016/j.chb.2004.11.012

Thompson, K. R., Lemmon, G., \& Walter, T. J. (2015). Employee engagement and positive psychological capital. Organizational dynamics, 44(3), 185-195. https://doi.org/10.1016/j.orgdyn.2015.05.004

Wellins, R., \& Concelman, K. (2005). Creating a culture for engagement. Workforce performance solutions, 4, 1-5.

Wilmar, B. S., \& Amold, B. B. (2006). The measurement of work engagement with ashort questionnaire: A cross-national study. Educational and psychological measurement, 66(4), 701-716. https://doi.org/10.1177/0013164405282471

Xanthopoulou, D., Bakker, A. B., Demerouti, E., \& Schaufeli, W. B. (2009). Work engagement and financial returns: A diary study on the role of job and personal resources. 


\section{Macrothink}

International Journal of Human Resource Studies

ISSN 2162-3058 2019, Vol. 9, No. 1

Journal of occupational and organizational psychology, 82(1), 183-200. https://doi.org/10.1348/096317908X285633

Xiao, M. L., \& Duan, L. (2014). Job engagement of employees in state-owned enterprises: Construct clarification and scale development. Organizational management, 1, 35-41. http://dx.doi.org/10.16471/j.cnki.11-2822/c.2014.01.017

Xie, W. H. (2006). Engagement (1st ed.). Beijing: China Business Press. pp. 30-31.

Xu, L., Guo, Y. J., \& Wang, Y. (2013). Empirical research on engagement structure ofmanufacturing employees based on structural equation modeling. Management world, 6 , 59-62. http://dx.doi.org/10.13529/j.cnki.enterprise.economy.2013.06.002

Yang, Y. (2005). The model of improving employee engagement. China human resource $\begin{array}{lll}\text { management } \quad \text { development, } & \text { 55(6), }\end{array}$ http://dx.doi.org/10.16471/j.cnki.11-2822/c.2005.06.015

Zeng, H., \& Han, J. L. (2005). To improve employee engagement. Enterprise management, 5, 9-10.

Zhang, Y. W., \& Gan, Y. Q. (2005). The Chinese version of Utrecht work engagement scale: An examination of reliability and validity. Chinese journal of clinical psychology, 13(3), 268-270.

Zhao, X. Y., \& Sun, J. (2010). A literature review on employee engagement. Journal of Beijing university of posts and telecommunications, 12(5), 93-98.

\section{Copyright Disclaimer}

Copyright for this article is retained by the author(s), with first publication rights granted to the journal.

This is an open-access article distributed under the terms and conditions of the Creative Commons Attribution license (http://creativecommons.org/licenses/by/4.0/). 